\title{
A review of policies and agricultural productivity in the arid and semi-arid lands (ASALS), Kenya: the case of Turkana County
}

Thomas E. Akuja1 and Jacqueline Kandagor ${ }^{2}$

Department of Dryland Agriculture, School of Agriculture, South Eastern Kenya University, P.O. Box 170-90200, Kitui, Kenya ${ }^{1}$

Turkana University College, Kenya ${ }^{1}$ (A Constituent College of MMUST), P.O. Box 69-30500, Lodwar

University of Kabianga, Kenya2, P.O. Box 2030-2020, Kericho

Corresponding author: akuja05@gmail.com

Original submitted in on $28^{\text {th }}$ June 2019. Published online at www.m.elewa.org/journals/ on $31^{\text {st }}$ August 2019 https://dx.doi.org/10.4314/jab.v140i1.9

\begin{abstract}
Objectives: This paper seeks to present a review of policies relating to agricultural productivity in the Arid and Semi-Arid Lands (ASALS) with a focus on Turkana County, Kenya.

Methodology and Results: This paper adopted a qualitative approach and data collection majorly relied on document analysis of policy papers, the Kenyan Constitution, parliamentary proceedings as recorded in the Hansard, academic papers, organizational journals, newspaper articles and government statutes relating to agriculture. Despite the culture of the people being centered on pastoralism, food security in the ASALs is far from adequate. The numerous policy documents reveal the efforts Kenya has made to increase Agricultural productivity. The successive governments though at varying degrees, developed plans that focused on rural areas albeit with little progress in the ASALS. Institutional failures and adverse policies are to blame for the growth of the Agricultural sector in Africa.

Conclusions and application of findings: There are numerous overlapping policies due to failure to evaluate existing ones. There is need to involve beneficiaries and to address resource allocation to agriculture to reflect the recommended $10 \%$ of overall country budget as per the Maputo agreement of 2003. Proper management of funds and fighting corruption is vital in effective implementation of development programs and realization of economic growth. Investment in both social and physical infrastructure (roads, livestock markets, abattoirs etc.) would ensure effectiveness of the various policies. There is need to prioritize water supply and water use efficiency for dryland agriculture.

Keywords: Agricultural productivity, rural Kenya, food security, Devolution, Policy, Development
\end{abstract}

\section{INTRODUCTION}

"Agriculture is the backbone of the country's economy," goes the cliché on the lips of many an African statesman and the introductory sentence in many a publication on Agriculture, but then how can it be explained that the continent whose population is predominantly rural suffers the highest levels of food insecurity and poverty? Over the years, there has been a decrease in the sector's contribution to the country's Gross Domestic Product (GDP). At independence, in 1963, the sector's contribution to the GDP 40\%, in the 1980s, it declined to $33 \%$ and in 2014 , it stood 
at $27 \%$ (KNBS, 2015). In 2016, it increased to 32.6 per cent from 30.4 per cent in 2015 (KIPPRA, 2017). The sector equally and indirectly contributes approximately 27.0 per cent to GDP through linkages with manufacturing, distribution and other service-related sectors. . The country's agriculture sector is dominated by smallholder farmers in rural areas hence making it an important sector in food security and poverty reduction.

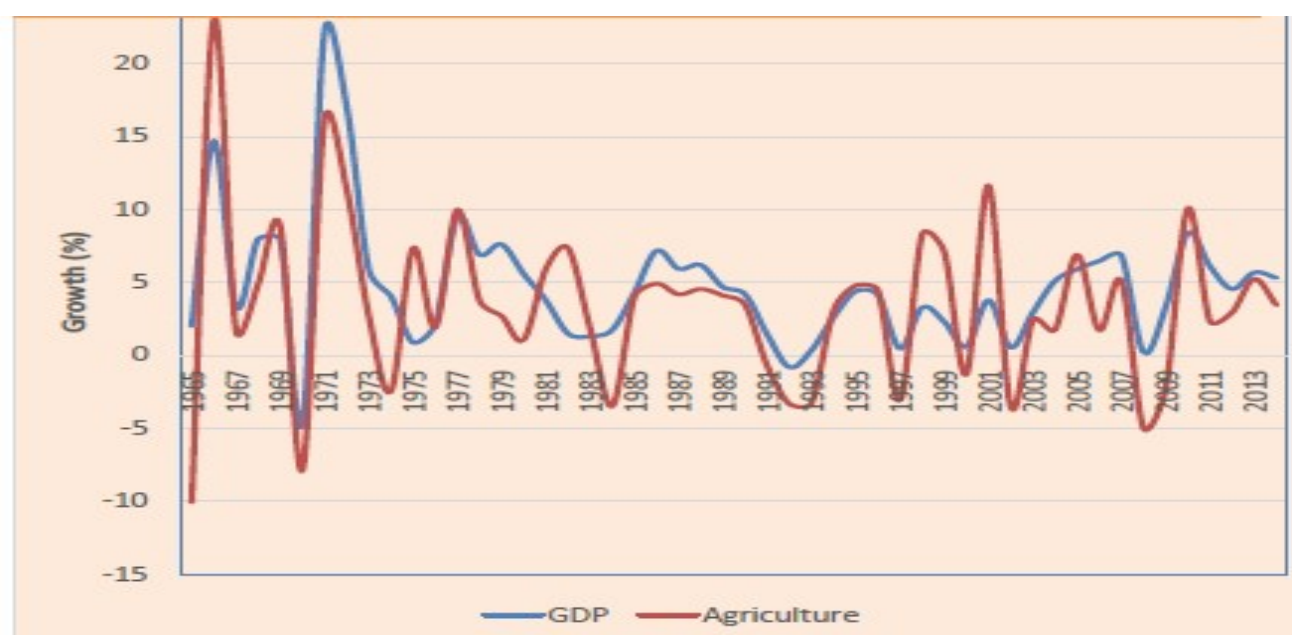

Figure 1: Growth of GDP versus Agricultural sector extracted from World Bank Data, 2016

From the chart above, there is a correlation between the country's economic growth and the growth of the agricultural sector. The Government of Kenya is cognizant of the role that agriculture plays in spurring the country's economy, ensuring food security and subsequently alleviating poverty (World Bank, 2016). Development theorists posit that for a country's economic growth there is need to shift from substance agriculture to wage employment in the manufacturing and service sectors otherwise known as structural transformation (Naseem et al., 2017). In spite of various concerted efforts to increase agricultural productivity since independence, there is little progress and hunger persists with the rural population being the hardest hit (Alila \& Atieno, 2006). It is enshrined in the Kenyan Constitution of 2010 Section 1 (c) that it is the right of every person "to be free from hunger and to have adequate food of acceptable quality." This shows the government's commitment to end hunger. In her study titled Determinants of Agricultural Productivity in Kenya, Muraya (2017) establishes that besides rainfall, inflation and government expenditure (policy) are the major determinants of agricultural productivity. Sarr (2018: 52) defines policy as "regulations, administrative actions, procedures, guidance, as well as incentives, a voluntary practice of government and other institutions". Decisions on policies are reflected in the allocation of resources. According to the World Bank(2007) agriculture impacts not only on food security but also poverty reduction, improvement of livelihoods, development of rural areas and environmental management, all of which contribute to economic growth. It is therefore expected that ending hunger and alleviating extreme poverty could have a direct impact on the county's economic growth ((KIPPRA, 2017). The Arid and Semi-Arid Lands cover $89 \%$ of Kenya's total land surface (29 out of 47 counties are classified as ASAL). The ASALs register the highest poverty rates, but with the advent of devolution following the promulgation of the new Constitution of Kenya, 2010, the management of resources has been taken closer to the people and therefore it would be interesting to discover if there are any changes. In order to effectively examine the impact of various government policies on agricultural productivity in Turkana County, it is necessary to give a brief presentation of the county tracing its history from independence to the present. 


\section{Turkana County}

Turkana County is the second largest county in Northern western Kenya covering 13\% of Kenya's land surface $\left(77,000 \mathrm{KM}^{2}\right)$. As per the last census by the Kenya National Bureau of Statistics in 2009, the population of Turkana stood at 855,399 with a growth rate of $6.4 \%$ per annum (FAO, 2013; Turkana County Government, 2016) the population in 2018 stands at 1,513, 465 assuming constant mortality and fertility rates. The vast county has a population density of 13 inhabitants per square kilometre with $85.8 \%$ of its population being rural and has one of the highest poverty rates in the country standing at 94.3\% (Commission for Revenue Allocation, 2009). Turkana is classified under Arid and Semi-Arid Lands characterized by low rainfall receiving an annual mean of 300 $400 \mathrm{~mm}$, high temperatures and sandy soils. Eighty per cent of the land is arid while $32 \%$ is arable and $3 \%$ is under rain fed agriculture particularly in Kakuma, Turkana West. The inhabitants of Turkana are pastoralists and the county has 12.4 million livestock comprising of cattle, sheep, goats, camels and donkeys. Sixty per cent of the population relies entirely on their livestock for their livelihood while $20 \%$ are agro-pastoralists, $12 \%$ rely on fishing on the shore of Lake Turkana and $8 \%$ rely on casual labour (FAO, 2013). The high number of livestock coupled with the environmental conditions pose a challenge considering the scarcity of water, pasture, droughts and conflicts that are recurrent the region (Oduor et al., 2012) Food insecurity is always triggered by drought and the county does not produce sufficient food for the population.

Table 1: Food requirement and production in 90kg bags, Turkana County

\begin{tabular}{l|l|l}
\hline Food type & $\begin{array}{l}\text { Requirements per year (90kg } \\
\text { bag) }\end{array}$ & Amount produced (90kg bag) \\
\hline Maize & 781,140 & 19,905 \\
Sorghum & 602,400 & 18,427 \\
\hline SO
\end{tabular}

Source: Ministry of Agriculture (2012)

Maize and Sorghum are the main foods consumed by the inhabitants of Turkana County. The above figures are of food produced under irrigation, a paltry quantity against the amount required to feed the ever-growing population (FAO, 2013). This disparity has resulted in aid dependency in the region that has also witnessed the proliferation of Non-Governmental Organizations (NGOs) over the last four decades. Kolding (1987) reports the first food aid intervention in 1962 by the British relief organization, Oxfam, and the Irish Catholic Mission, and these organizations have been in Turkana ever since. Religious organizations, particularly the Catholic Church, have been instrumental in the provision of services in the county ranging from health to education, irrigation and cash transfer programs Migosi et al., 2012; Oduor et al., 2012). According to the National Irrigation Board (2017), 29,100 acres are under irrigation in Turkana and the major crops cultivated are maize and sorghum. Of the 47 counties, Turkana County receives one of the highest revenue allocations (CRA, 2009). With these two points taken into consideration it would be expected that the county is food secure. Statistics show that the twin problems of poverty and food insecurity persist in Turkana. Prior to the promulgation of the new Constitution of Kenya, 2010, numerous scholars have tied Turkana's woes to the colonial regime and marginalization by the successive post-independence regimes under the inherited constitution (Nyanjom, 2014; Gow \& Parton, 1992; Abdullahi, 1997). It is against this background that this paper seeks to establish the impact of the various government policies on agricultural productivity in rural Kenya with Turkana County as a case study. 


\section{MATERIALS AND METHODS}

This paper adopted a qualitative approach and data collection majorly relied on document analysis of policy papers, the Kenyan Constitution, parliamentary proceedings as recorded in the Hansard, academic

\section{RESULTS AND DISCUSSION}

\section{Government Policies and Agriculture (1900 to the} present)

Colonial era 1900 -1963: Before the colonialists arrived in Africa, most communities were either food secure or had their own coping mechanisms. Gichure (2017)) notes that over time pastoralists have practiced food preservation. Among the reasons for abandonment of the practice, Teshome and Bayissa (2014), list urbanization, population increase and climate change. The arrival of the colonialists destabilized communities' way of life. In reaction to the resistance by communities in Northern Kenya particularly the Somali people, and in effort to control them, the colonial regime created the Northern Frontier District (NFD) in 1902 (Abdullahi, 1997). Turkana District was integrated into the NFD in 1920 implying that the region became closed to outsiders (KNA, official gazette, 1920). Apart from succeeding in policing the region, the government had not carried out any development project. The neglect and ensuing marginalization of the region is attributed to the colonialist's perception that the region was unprofitable and that the small population did not merit attention while there was so much to be done in the more productive and densely populated areas of the colony (Abdullahi, 1997). There was a development plan (KNA PC NFD/5/1/8, POST WAR Five Year Development Plan, 1945), but it mainly focused on water schemes and grazing control in effort to resolve conflicts amongst the various groups in the NFD. The colonial government did not see the need to develop the region that it considered barren. It is this attitude towards Turkana that led to the setting up of a prison in Lokitaung to incarcerate political prisoners. It is in the same prison that Jomo Kenyatta was imprisoned years later. Akall (2014) reports that during this era there were irrigation projects in Turkana mainly to produce food for the prisoners. In 1945, the colonial government set up the African Land Development Board (ALDEV) that focused on water development and rangeland management by reducing the land sizes within settler control. The policy lauded for being the first real policy specifically aimed at intensifying ASAL production after the Second World War aimed at papers, organizational journals, newspaper articles and government statutes relating to agriculture. Despite the culture of the people being centered on pastoralism, food security in the ASALs is far from adequate.

developing African lands and stemming the tide of population pressure that could lead to political unrest (Ominde, 1971). The budget allocated to the ASALs as evidenced in the ALDEV Expenditure in the African Land Areas (1946-1962) reveal a discrepancy in funds to the ASALs. Turkana District was allocated $£ 14,251$, Garissa received $£ 4,149$ and Wajir did not receive any funds, while Nyeri and Kwale received £159,378 and $£ 270,933$ respectively. The funding was spent mostly on small-scale irrigation schemes, which proved to be very expensive though productive. Detainees who worked half-heartedly and often deserted (Ominde, 1971) attributed the failure of the schemes to the desertion. Following the challenges faced by ALDEV, the Swynnerton Plan was drawn up in 1954 in response to the land crisis in Central Province. Lauded as one of the most comprehensive of all the post-war colonial development schemes, the plan recognized the need to develop the marginal areas. The plan was intended to address African land problems by reforming land tenure and to consolidate fragmented land holdings, issue freehold title to intensify and develop African agriculture through the provision of access to credit and to remove restrictions of growing of cash crops for export. (Swynnerton, 1954). The plan recommended that in order to benefit economically benefits from these lands, pastoral communities should embrace rigorous grazing management, which included regulating the number of livestock, provision of regular outlets (markets) for the absorption of excess livestock, government investment in adequate and permanent water supply as well as pest and disease control. The plan however did not benefit the communities in the ASALs, for it failed to understand that pastoralists keep large numbers to cope with drought (Njeru et al., 2017)

Kenyatta Regime 1963 - 1978: At independence in 1963, Jomo Kenyatta's regime inherited an economy characterized by regional inequality and imbalanced distribution of resources. Therefore, Jomo Kenyatta regime made a deliberate choice to focus its development projects on the most productive regions to speed up the country's economic development. In the sessional paper No.10 of 1965 on African Socialism and its application to planning in Kenya, decisions were 
made in order to accelerate development in the then young nation. Gow and Parton (1992) note that the economic policy in post-independence Kenya aimed at growing per capita incomes equitably distributed while focusing on fighting disease, poverty and exploitation. Kenya's first five-year national development plan (NDP) (1966 - 1970) set out a program of diversifying the economy and focusing on industrialization. This led to the neglect of agriculture at the expense of industrialization. Nevertheless, the agricultural sector's income rose during the period suggesting that agriculture still thrived in spite of the unfavourable policy environment. During the first ten years after independence, the government's budget for the agricultural sector budget was devoted to land transfers and resettling natives on previously European-owned farms. Hinderlink and Sterkenberg (1987) posit that government policies favoured large farms, export crops and farming in high potential areas. Turkana like most areas in the ASAL region did not benefit from this budget for neither large-scale farms nor cash crops exist in Turkana even at the present. However unimplemented, there were policy changes to encourage livestock production in the ASAL areas and experimentation with integrated rural development projects (Gow \& Parton, 1992). Special Rural Development Program (SRDP) was introduced in 1967 and it ended in 1974. The inception of this program is traced to a report by the National Council of Churches on youth unemployment (Ergas, 1982). Initially rolled out on a pilot basis, the program covered 6 districts and funded by six donor powers with the ultimate objective of spreading to the rest of the country (Barkan and Chege, 1989). Its activities included the training of farmers and engagement of the youth in road construction. Barkan and Chege (1989) attribute the program's failure to mismanagement of funds, understaffing and the fact that the donors had opted to work without involving the government that it had deemed corrupt. In view of this failure, the SRDP was phased out and integrated into the District Development Program (Ndalila, 2015). It is the second NDP 19701974 under the theme Rural Development that the government recognized that need to focus on rural development to spur national development. The third NDP 1974-1978 themed Employment and Income Distribution put in place procedures for the planning and implementation process but did not go beyond the production of the District Development Plans (Kirori, 2015). The fourth NDP 1979 - 1983 under the theme Alleviation and Poverty gave emphasis to the need to diversify activities in rural areas so as to move from small scale agriculture to industrial and non-rural farm activities as well as to increase community participation in decision making. In the late 1960s, small-scale irrigation was initiated in the ASAL areas of Turkana and Garissa through funding from UNDP/FAO, NORAD and the World Bank (Wasilwa, 2007; Akuja, 2012). The farms were developed to increase food security and to address the perennial famines and droughts among the nomadic communities. In Turkana, the irrigation projects were developed in Katilu, Amolem and Turkwel, and were implemented in 5 to 10 year cycles and that they always ended in failure (Akuja, 2012).

Moi regime 1978 -2002: When Daniel arap Moi succeeded Jomo Kenyatta in 1978; he inherited a highly clientelist regime and imbalanced regional development (Barkan \& Chege, 1989). To remedy the situation and ensure an equitable distribution of resources, Moi's regime fully adopted the District Focus Strategy in 1983 (Sigei, 1987; Kirori, 2015). In the fifth National Development plan of 1984-1988 under the theme Mobilisation of Domestic Resources, the government transferred the responsibility of planning and implementation from the central government to the district level. This form of decentralization had been viewed as a way of effectively addressing the needs of the locals at the district level and to have them participate in decision-making on projects to prioritize in their localities. Another motivation for the adoption of the District Focus Strategy is attributed to the fact that donor funding was tied to decentralization by newly independent African states (Sigei, 1987) Moi's regime therefore succeeded in appeasing donors that the strategy would ensure equal distribution of development throughout the country and benefit the rural areas. Moi's regime inaugurated the District Focus for Rural Development (DFRD) in 1983 to channel funds through the District unlike Kenyatta's regime that channelled development through the provincial level, which without doubt was not effective at reaching the locals. The biggest challenges to the effectiveness of the District Focus Strategy (DFS) were the staffing of the District Development offices and the constitution of the District Development Committees. As evinced in the proceeding of parliament of $8^{\text {th }}$ July 1986, the district development office was understaffed with one district development officer (DDO) and a telephone operator. The officer's job entailed coordinating all the development projects of the ministries at the district level and taking minutes of the various committee meetings. This onerous responsibility bestowed upon 
the DDO resonated with the World Bank's (1975) definition of a national programme for rural development that specified that such a programme should include activities ranging from increasing Agricultural output, employment creation and improving health and education as well as expanding communication and improving housing. The other challenge in the planning and implementation of the DFS is in relation to the composition of the district development committee comprised of members from the community who were there to advance the views of politicians (Sigei, 1987). The inefficiency of the district development committees often resulted in underutilization of funds. For example, $£ 62,000$ in unutilized funds meant for development in Turkana District during the financial year 1985/1986 were returned to treasury (Hansard, $8^{\text {th }}$ July, 1986). The other challenges include: the District Commissioners (DC) lack of control over the expenditure of the funds and worse still had no control over the professional in the various fields. The DCs often failed to call for meetings on regular basis. Cognizant of the aforementioned challenges, District Development Officers (DDOs) were recruited and sent to the districts, but they often had neither the qualifications not the experience for the job (Wallis, 1982). The DDOs were eventually integrated into provincial administration as District Officers with no development portfolio (Sigei, 1987). In 2000, the government launched the first phase of the National Agriculture and Livestock Extension Programme (NALEP I) in collaboration with the Swedish International Development Agency (SIDA). The programme was implemented in some 43 districts drawn from 5 provinces and it was drawn such that it was in line with both the Kenya Government Policy on decentralization as well as Agriculture as documented in the Revitalisation of Agriculture (SRA) launched in 2004. NALEP | ran from 2000 to 2005 and NALEP || ran from 2006 to 2017.

Kibaki regime 2002 - 2010: It is during Mwai Kibaki's regime that important institutional reforms took place including the promulgation of the Constitution of Kenya (2010) that led to the establishment of a two-tier government: one National government and 47 County governments. A number of funds were established during this period and they include The Constituency Development Fund (CDF) in 2003; The Free Primary Education Fund (2003); The Secondary Schools Education Bursary Fund (2003); The Civil Servants Housing Scheme (2004); The Disability Fund (2004); The Women Enterprise Fund (2006) The Economic
Stimulus Package (2009). Of particular interest to this paper on agriculture are the CDF and the Economic Stimulus Package. The CDF was intended to meet the socio-economic objectives that were initially under the central government, that is, finance projects that would ameliorate the lives of the citizens by funding development projects and fighting poverty alleviation (Ndalila, 2015). The constituents were expected to submit proposals to the District Projects committees that would in turn consult the constituents to reach a consensus on the projects to fund. The responsibility of the implementation of the project lies with the head of the project committee. Various scholars (Owalla, 2012 Ndalila, 2015 ;) have documented the challenges that the CDF faced in spite of its relative success. Top of the list of these challenges is governance issues, total failure to implement or partial implementation of projects and the interference of politicians especially the members of parliament who are the patrons. The court however declared the existence of the CDF unconstitutional. A review of the CDF budgetary allocations for the financial year 2015/2016 for Turkana County show that most of the funds was used in infrastructure(roads), education(bursaries and classrooms), capacity building. Between 2011 and 2012, the government formulated the Agriculture Sector Development Support Program (ASDSP) that was to run between 2010 and 2020. The main objective of the program jointly supported by both the Kenyan and Swedish governments was to achieve an agricultural growth rate of $7 \%$ per year through commercialization and modernization of the sector. This is expected to ultimately contribute to poverty reduction, improved food security, and equity in rural and urban Kenya. A mid-term review carried out by SIDA established that the program was ineffective due to governance issues, the flow of funds through the government system resulting in delays. In Turkana, the program implemented entailed goat meat value chain (Turkana County Goat meat value chain) which has been reported to be equally ineffective due to drought, insecurity(cattle rustling), lack of markets among others (Matete and Shumba, 2015)

Jubilee regime 2013 to the present: Devolution takes resource management to the grassroots and is seen as a solution to driving the economy by addressing the unique challenges faced by the specific regions. As stipulated in the Fourth Schedule (Constitution of Kenya, 2010) certain functions were devolved to County Governments and Agriculture is one of them. Besides Agriculture and Irrigation; Livestock, Fisheries 
and Veterinary Services, the other devolved functions include Finance and Economic planning; Roads, Public Works and Transport; Health and Sanitation; Education and ICT; Trade, Industry and Cooperative Development; Land, Housing, Physical planning and Urban Development; Water Development, Environment and Natural Resources and Tourism, Culture, Sports and Social Development. There is need to point out that all the other functions impact on agricultural productivity in one way or another, for example,Transport (infrastructure), Finance (funding of agriculture related projects),Trade, Industry and Cooperative Development (financial empowerment for the farmers, marketing of produce), Land (land use is core in Agriculture especially in regions where land is owned communally owned - the case of rural African peoples), Physical Planning and Urban Development (considerations on animal auction fields, factories), Water Development (Agriculture is highly dependent on availability of water), Environmental and Natural Resources and Tourism (Agricultural productivity is highly influenced by environmental factors). The national government retains much control over the agricultural sector under the State department of Agriculture, State department of livestock and State department of fisheries. In 2018, the Jubilee regime is in the second term since devolution and various researchers have documented the impact of devolution on the agricultural sector. Poulton (2009) asserts that agricultural functions were devolved premised on the inclusion of local stakeholders in identifying areas that need prioritization, budgeting and planning to ensure that services rendered match the people's local needs. County Integrated Development plans (CIDPs) were developed by each of the 47 counties to address the unique challenges each region faced. According to the Kenya Bankers report (2016), the first County Integrated Development plans were hastily drafted to enable counties to access finance and therefore benefitted

\section{DISCUSSION}

The numerous policy documents and reports consulted in this study reveal the efforts Kenya has made efforts to increase Agricultural productivity. The successive government regimes, though at varying degrees, developed plans that focused on rural areas albeit with little progress in the ASALS. Binswanger and Townsend (2000) posit that institutional failures and adverse policies are to blame for the growth of the Agricultural sector in Africa. Both decentralization and devolution processes have been used as means of from neither sufficient analysis nor consultation with the stakeholders. The CIDPs were anticipated to help vision 2030 goals and the implementation of these plans are hindered by poor prioritization of funding, poor financial management, delay in release of funds and Human Resource related challenges. Pointless to add that there is conflict in service provision in the sector due to the doubling and overlapping of roles. Ngotho (2015) reports of farmers' failure to benefit from subsidized fertilizer due to confusion on their part on whether it was the national government or county's role. Vision 2030: Kenya Vision 2030 is Kenya's development blueprint covering the period the period 2008 to 2030. The document gives Agriculture in the ASAL region considerable attention. By 2017, the government targeted to put 404,800 hectares under irrigation especially in Turkana and Tana Delta (Kenya Vision 2030, 2011) Apart from irrigation, the other of focus under the Economic and Macro Pillar are Fisheries, Establishment of Disease Free Zones, Fertilizer cost reduction and Implementation of the consolidated Agricultural Reform Legislation.

Big Four Agenda: Launched in 2017 as part of vision 2030, the action plan focuses on Food Security, Affordable Housing, Affordable Healthcare and Manufacturing. Cognizant of the role of Agriculture as a key driver of economic growth and the need to attain food security, the government targets to increase production of maize, the country's staple food from 40 million 90kg bags annually to 67 million bags in 2022 . The other crops targeted include rice and potatoes. The implementation of the project has been marred with allegations of misappropriation of funds and mismanagement. The implementation of the Big Four Agenda has also been hampered by a lack of coordination between the national government and the county governments (Ministry of Devolution and Planning, 2017).

improving service delivery and implementation of projects in the rural sector, but with little progress. While decentralization entails shifting planning and implementation of projects from the central government at the capital city to offices in the grassroots, control of funds is remains centralized (FAO, 2006). Devolution on the other hand entails the transfer of functions to the local level such that the responsibility of planning, resource allocation and implementation of projects lies entirely with the people at the local level (Allan, Lowden 
and Thorp, 2001). Under both processes of decentralization and devolution, government policies, reports and resource allocation reveal the country's recognition of the role that the agricultural sector plays in the economic development and subsequent commitment to rural economy through policy prescription and budgetary allocation. Over the years, the country's budgetary allocations for agriculture have been on the rise though not meeting the 10\% threshold of national budget agreed upon during the Maputo declaration (2003). It is however important to point out that ironically the budgetary allocation for agriculture is controlled from the national government yet the identification of the local needs is at county level. To illustrate this irony, the total budget for the financial year $2017 / 2018$ is 3.07 trillion and while $12.4 \%$ is divided amongst the 47 counties, $87.6 \%$ is taken by the national government distributed as shown in Figure 2 below.

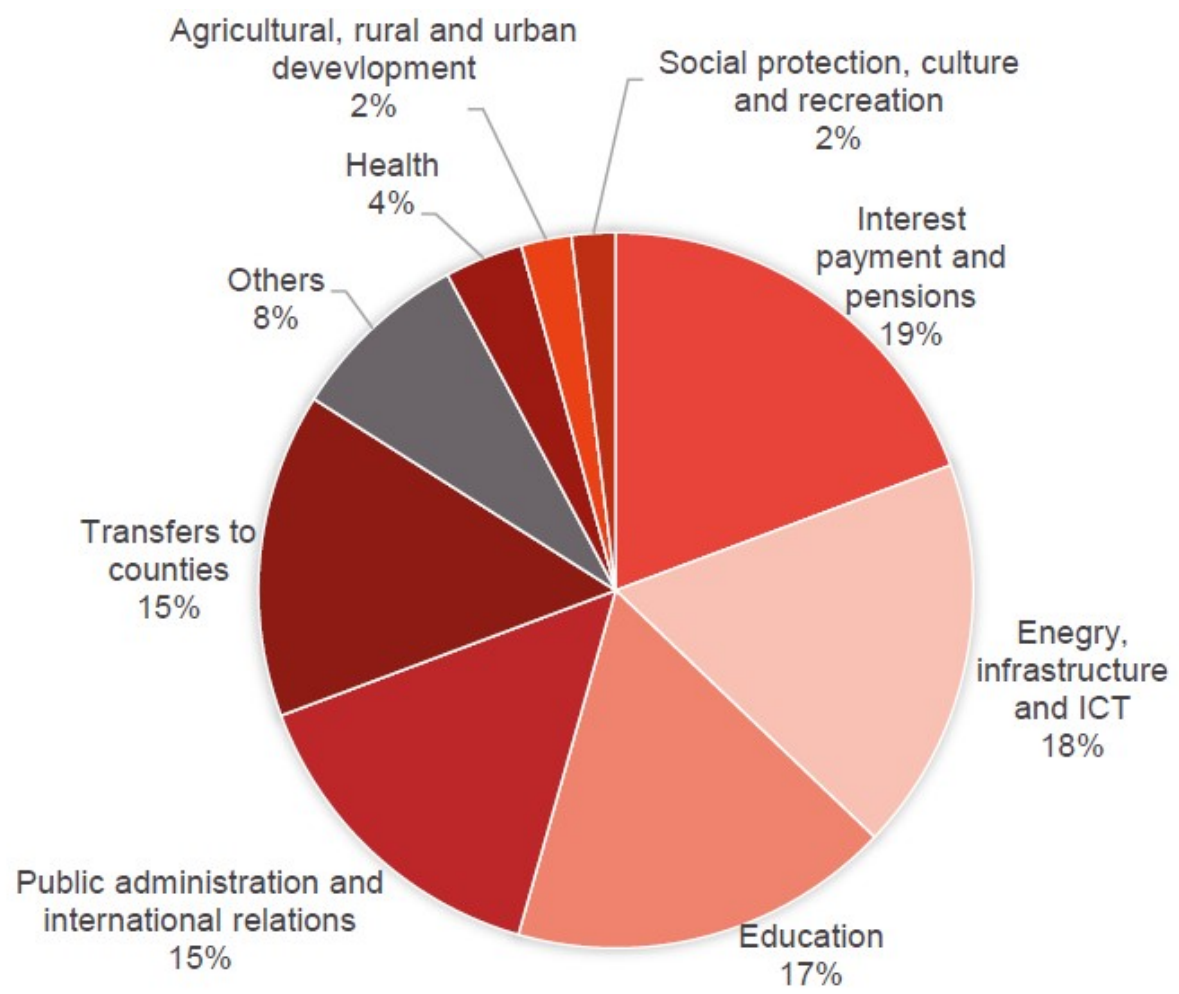

Figure 2: Kenya's budget allocation to sectors 2018/2019 Development Initiatives (DI) based on 2018/19 budget data

The 2\% allocated to agriculture supports Crop Development and Management, Agribusiness and Information Management, Irrigation and Drainage Mechanization Infrastructure, Livestock Resources Management and Development, Fisheries Development and Management, Land Policy and Planning, National Land Information Management System, Land disputes and conflict resolution, Land Administration and
Management, General Administration, Planning and Support Services for the five subsectors(Republic of Kenya, 2018). The low budgetary allocation for agriculture at the national level is reflected in the County Level. Turkana County Government allocated $5.04 \%$ of its total budget to Agriculture; an allocation that is was below the $10 \%$ recommended in the Maputo 2003 declaration. 

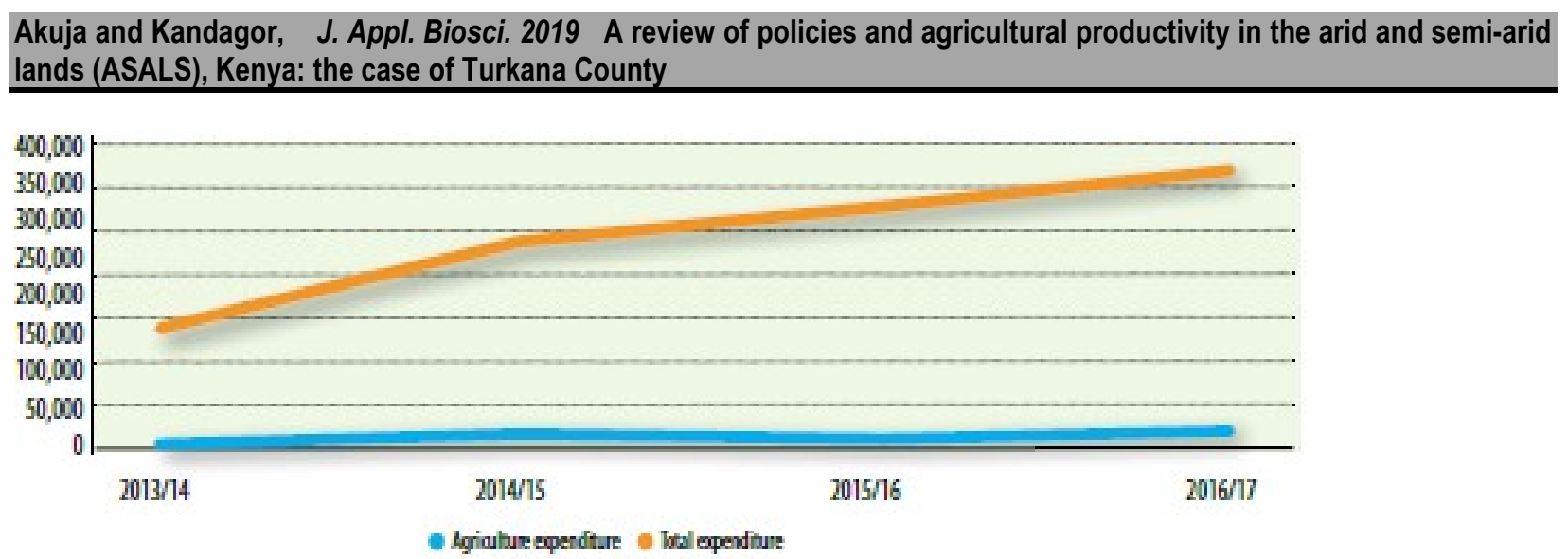

Figure 3: Comparing between agriculture and total budget at the County level extracted from Kenya Bankers Association Report (2018)

A number of challenges in the implementation of the development projects can be traced to management of funds and lack of coordination between Nairobi and the field officers. (Sigei, 1987; Kirori, 2015) Governance issues have been blamed for the failure of many projects. Igwadah (2014) reports of irregular tendering processes in irrigation that led to the loss of 953 million shillings. Decentralization given its top-bottom approach succeeds depending on the commitment of the political authority while devolution is more of a bottom-top approach and is people driven (Bob, 1998). While explaining the collapse of the fisheries project on the shores of Lake Rudolf(presently Lake Turkana), BrochDue (1986) writes that the Turkana Fisheries Cooperative society(TFCS) was initiated to meet the need felt by the aid agencies (in this case NORAD) but not the needs felt by the fishermen themselves - the locals. FAO (2013) reports the same predicament about the collapse of irrigation schemes along river Turkwel. Failing to involve the beneficiaries, that is the locals, has been the reason behind the failure of many a donor-funded project. Sigei (1987: 14) observes that "the rapid deployment of government personnel to rural areas had favourable impact on the development of

\section{CONCLUSION AND APPLICATION OF FINDINGS}

Based on the findings above, increasing agricultural productivity in rural areas is key in attaining a country's development goals. Existing policies suffice to effectively develop the rural areas however, there is need to address the following factors to ensure their efficient implementation of projects.

- $\quad$ Resource allocation - the amount allocated to agriculture is low and needs to be increased to the recommended $10 \%$ of overall country budget as per the Maputo agreement of 2003. agricultural, commercial and industrial production. Rural farmers lack exposure to modern technologies that would help them in improving their farming activities and consequently increasing agricultural productivity. Therefore there is need to increase access to technology in rural areas. This knowledge transfer could be facilitated by extension services provided to farmers. While noting that there is inadequate policy on agricultural extension, Chimoita (2014) posits that agricultural extension programmes are key policy instruments used to foster agricultural productivity in many parts of the world. Increasing agricultural productivity prevails under certain favourable conditions like investment in infrastructure and access to social amenities by the locals. According to the World Bank (1990), there is a strong link between rural development and provision of services such as credit facilities, technology and infrastructure. Nyanjom (2014) posits that the marginalization of the ASAL region meant that the pastoralists' livestock remained more of a sociocultural than economic asset. The lack of social and physical infrastructural investments in the region denied the inhabitants access to markets beyond its borders.

- $\quad$ Proper management of funds - fighting corruption is vital in effective implementation of development programs and realization of economic growth.

- Investment in infrastructure (roads, livestock markets, abattoirs etc.) would have an indirect impact on agricultural productivity

- Coordination: Streamlining policies on devolution to avoid duplication and overlapping of mandates between the National government and the county government 
- $\quad$ Participation of the people in development projects - by involving the people they end up taking ownership of the projects hence increasing achievement of objectives...

- $\quad$ Need to focus on the various agricultural sectors; crop production, livestock production and fisheries.
- $\quad$ Provision of extension services to farmers in rural areas to increase farmers' access to new technology and innovations for efficient farming methods.

\section{ACKNOWLEDGEMENTS}

Many thanks to the County Government of Turkana for data on budgetary allocations and reports on Agriculture in the County.

\section{REFERENCES}

Abdullahi A, 1997. Colonial policies and the failure of Somali Secessionism in the Northern Frontier District of Kenya Colony, c. 1890 -1968. MA Thesis. Rhodes University.

Akall G, 2014. Narratives \& Local Perspectives on Irrigation Development in Turkana: Case of Turkwel, Loima sub-County. DLCl Workshop on Water and Irrigation Planning Wed 10 September, St. Teresa Pastoral Centre, Lodwar. http://www.fao.org/fileadmin/user up load/drought/docs/DLCl\%20Workshop\%20Lod war\% $2010 \% 20$ Sept.pdf

Akuja TE, 2012. How to address hunger in Turkana. Nairobi: The Star https://allafrica.com /stories/201202210594.html

Alan A, Lowden P, and Thorp R, 2001.Decentralizing Development: The Political Economy of Institutional Change in Colombia and Chile Oxford: Oxford University Press

Alila P. and Atieno R, 2006. Agricultural Policy in Kenya: Issues and Processes. IDS, University of Nairobi. http://www.fao.org/fileadmin/user _upload/fsn/docs/Ag_policy_Kenya.pdf

Barkan J. and Chege M, 1989. 'District Focus and the Politics of Reallocation in Kenya' Journal of Modern African Studies (Cambridge University Press) 27(3): 431 - 439

Binswanger HP. and Townsend RF, 2000. The Growth Performance of Agriculture in Sub-Saharan Africa. American Journal of Agricultural Economics 82(5): 1075-1086

Broch-Due V, 1986. From Herds to Fish and from Fish to Food Aid: A Socio-anthropological case study. (Draft) NORAD

Chimoita LE, 2014. Review of Agricultural Extension Interventions in unlocking Agriculture Potential through Medium Sized farms, Kenya.
Technical Report to Equity Group Foundation, Agriculture Pillar.

Djurfeldt G, Holmen H, Jirstrom M, Larsson R. (Eds.), 2005. The African food crisis: lessons from the Asian Green Revolution Wallingford, UK: CABI.

Ergas, Z.R., 1982. Kenya's Special Rural Development Program (SRDP): Was it really a Failure? The Journal of Developing Areas, 17: 51-66.

FAO 2015. Analysis of Public expenditure in support of food and agriculture in Kenya, 2006 -2012. Technical notes series, MAFAP, by Laibuni, NM, Mathenge, N, Kirui, L, Omiti, J. O, Rome

FAO 2013. Food indicators. http://www fao.org/economic/ess/ess-fs/ess fadata/en/\#.VBc502NUTAk

FAO 2006. Understand, analyse and manage a decentralisation process. http://www.fao.org /3/a-a0876e.pdf

Gichure JN, 2017. Integrating Traditional Techniques into Conventional Preservation Methods to Upgrade Pastoral Deep-Fried Beef Products in Kenya. Unpublished PhD Thesis. University of Nairobi.

Gow J and Parton KA, 1992. The Evolution of Kenyan Agricultural Policy. Paper Presented to the Australian Agricultural Economics Society Conference, Canberra, February 1992. https://pdfs.semanticscholar.org/389d/930838 9137829fa7d460063f69a56780c81f.pdf

Hassan M, 2013. District Creation under President Moi. https://pdfs.semanticscholar.org/ab30/abc5150 f1b5d6b92391c0f5a7b0400ff9819.pdf

Hinderink J. and Sterkenburg J, 1987. Agricultural Commercialization and Government Policy in Africa, KPI, London. New York: Methuen.

Igwadah L, 2014/12/14. How Sh953 million scandal turned Turkana Food Security Project into a 
pipe dream. Daily Nationhttps://www.nation.co.ke/business/HowSh953-million-scandal-turned-Turkana-foodsecurity-project/996-3485830r50wiez/index.html

Kenya ASAL Policy 2012. National policy for the sustainable development of northern Kenya and other arid lands. Sessional paper No. 8 of 2012, Nairobi, Republic of Kenya.

Kenya National Assembly Official Record (Hansard) June 11 - July 31, 1986.

Kirori GN, 2015. Rural Development Policies in Kenya: A descriptive analysis over 1970 - 2001 period. European Journal of Business, Economics and Accountancy. 3(1): 35 53.https://www.idpublications.org/wpcontent/uploads/2015/01/RURALDEVELOPMENT-POLICIES-IN-KENYA-ADESCRIPTIVE-ANALYSIS-OVER-1970-2001PERIOD.pdf

KIPPRA, 2017. Kenya Economic Report 2017: Sustaining Kenya's Economic Development by Deepening and Expanding Economic Integration in the Region. Nairobi: KIPPRA. http://kippra.or.ke/wp-content/uploads /2017/05/KER-2017-Popular-Version-1.pdf

Kolding J, 1987. The History of Lake Turkana and role of TFCS and Norad. Bergen: Institute of Marine Research. https://www.academia.edu 19517045/The history of Lake Turkana fishe ries_and_the_role_of_TFCS_and_Norad?auto =download

Maputo Declaration, 2003. Assembly of the African Union, Second Ordinary, $10-12$ July 2003, Maputo, Mozambique.

Matete G, Shumba C, 2015. Market-driven chain for the livestock sector Turkana County. Report submitted to Oxfam GB and the Turkana County Livestock Production Office. https://cng-cdn.oxfam.org/kenya.oxfam.org /s3fs-public/file_attachments/Marketdriven $\% 20$ value $\% 20$ chain $\% 20$ for $\% 20$ the $\% 20$ li vestock $\% 20$ sector, $\% 20$ Turkana $\% 20$ CountyPublished.pdf

Migosi J, Nanok D, Ombuki C, Ombuki KN, Evusa Z, Metet J, 2012. Determinants of primary school access and participation in the pastoralist Turkana County. Universal Journal of Education and General Studies 1(11): 348 355
Ministry of Devolution and Planning, 2017. Implementation of the Agenda 2030 for Sustainable Development in Kenya. http://planning.go.ke/wpcontent/uploads/2018/04/SDGImplementation-plan-2030.pdf

Muraya BW, 2017. Determinants of Agricultural Productivity in Kenya. M.A Thesis. University of Nairobi. http://erepository.uonbi.ac.ke /bitstream/handle/11295/102347/Muraya_Dete rminants\%20of\%20Agricultural\%20Productivit y\%20in\%20Kenya.pdf?sequence=1\&isAllowed $=y$

Naseem A, Oehmke FJ, Anderson J, Mbaye S, Pray C, Nagarajan L, Moss BC, Post LA, 2017. Measuring Agricultural and Structural Transformation. Selected Paper prepared for presentation at the 2017 Agricultural \& Applied Economics Association Annual Meeting, Chicago, Illinois, July 30-August 1. http://ageconsearch.umn.edu/record/258549/fil es/Abstracts_17_05_24_11_53_08_19_165 230_224_216_0.pdf

Ndalila NM, 2015. Bridging the gap between law and practice at the counties Unpublished Master's Thesis. University of Nairobi. Accessed online on 21th October, 2018. http://erepository.uonbi.ac.ke/bitstream/handle $111295 / 99251 /$ Ndalila_Strengthening $\% 20$ the $\%$ 20management $\% 20$ of $\% 20$ devolved $\% 20$ funds \%20in\%20Kenya.pdf?sequence=1\&isAllowed =y

Ngotho A, 2015. December 15. Duplication of roles affecting farmer's productivity. https://www.thestar.co.ke/news/2015/12/15/duplication-ofroles-affecting-farmers-productivity c1259466

Njeru TN, Kirimi L, Nthenya K, 2017. The Evolution of Collective Land Access Regimes in Pastoralist Societies: Lessons from East African Countries. Annual World Bank Conference on Land and Poverty. Washington, Dc: The World Bank.

Nyanjom O, 2014. Remarginalising Kenyan Pastoralists: The Hidden Curse of National Growth and Development. African Study Monographs. 50:43-72

Oduor A, Cherogony C, Mutune J, Malesu M, Karuma A, Nyolei D, Kandagor J, Onyango D, 2012. Food Security Masterplan for Turkana County. Lodwar: Diocese of Lodwar. 
https://www.worldagroforestry.org/publication/f ood-security-master-plan-turkana-county

Ominde SH, 1971. 'The semi-arid and arid lands of Kenya' in S, H. Ominde (ed.) Studies in East African Geography and Development. Heinemann Educational Books, Nairobi, p. 146.

Owalla, C. (2012). A Report on Management of Devolved Funds: A case Study of Kisumu Minicipality.A Network of Civil Society Organization-Ufadhili Trust.

Poulton C, 2009. "Agricultural research', in Kirsten, J.F et al (Eds), Institutional Economics Perspectives on Agricultural Development. Washington, DC: International Food Policy Research

Republic of Kenya (2018) Agriculture Rural and Urban Development (ARUD) Sector Report: Medium Term Expenditure Framework 2018/19 2020/21. http://www.treasury.go.ke/compon ent/downloads/send/194-2018/706-agricultureand-rural-development-sector.html? option=com jidownloads

Republic of Kenya, 2011. Kenya Vision 2030. Online. http://www.vision2030.go.ke/index.php

Republic of Kenya, 2010. Kenya Population and Housing Census, 2009

Republic of Kenya, 1982. Report and Recommendation of Working Party on Government Expenditure. Chaired by P. Ndegwa. Nairobi: Government Printer

Sarr F, 2018. Role of Sustainability Impact Assessment in Public Health Policy Change. Banjul: CENMEDRA.

Sigei FK, 1987. The District Focus for Development Strategy in Kenya: A case of Decentralization and Changing Role of the Generalist Administration. M.A Thesis. University of Birmingham.

Swynnerton RJM, 1954. A Plan to Intensify the Development of African Agriculture in Kenya. Nairobi: Government Printer.

Teshome J. and Bayissa, Z, 2014. A Literature Report on Understanding the Context of People Transitioning out of Pastoralism (TOPS) in Ethiopia. Addis Ababa: Haramaya University

Turkana County Government, 2016. Turkana County Second Annual Development Plan 2015/2016

Wallis $M, 1982$. Bureaucrats, Politicians and Rural Communities in Kenya. Papers on
Development Issue no. 6.University of Manchester.

Wasilwa LA, Esilaba AO, Moi T, Wasike VW, Kubaso S, 2007. The Current Status of Date Palm Production and Utilization in Kenya. African Crop Science Proceedings. 8: 2209 - 2252. Elminia, Egypt: African Crop Science Society.

World Bank, 2007. World Development Report 2007: Agriculture for Development. Washington, DC: The World Bank.

World Bank. 2016. The World Bank Annual Report 2016. Washington, DC. The World Bank.

World Bank. 1990. World Development Report 1990: Poverty. New York: Oxford University Press. 